\title{
Condiciones esenciales para el crecimiento de la cultura según T.S. Eliot
}

\author{
Helena Ospina Garcés \\ Escuela de Lenguas Modernas \\ Universidad de Costa Rica
}

\begin{abstract}
Resumen
El objetivo de este trabajo es entresacar del ensayo de T.S. Eliot, Notes towards the Definition of Culture su concepto de cultura y la importancia de los estudios culturales en la pedagogía de lenguas y en el desarrollo de la sociedad actual. T.S. Eliot se pregunta si existen unas condiciones esenciales para el crecimiento y la sobrevivencia de la cultura. Para Eliot la interacción entre la cultura del individuo, la del grupo, y la de la sociedad, como un todo, es fundamental. En este marco de ideas daré a conocer la experiencia de dos proyectos de la Escuela de Lenguas Modernas: el Proyecto ED-2080 Encuentro Mesoamericano "Escritura-Cultura", que desde el año 2006 viene reflexionado sobre esta interacción -individuogrupo-sociedad-, y planteando la centralidad de la persona humana como base de una auténtica cultura y desarrollo; y el proyecto de investigación No. 23-B3-194 Investigaciones Literarias de obras en lenguas modernas (alemana, francesa, inglesa, italiana): Estudio y comentario del plan de lecturas del Ministerio de Educación Pública, que desde el 2013 viene abordando un enfoque axiológico y personalista en su crítica literaria.
\end{abstract}

Palabras claves: T.S. Eliot, Notes towards the Definition of Culture, individuo-grupo-sociedad, persona, cultura, condiciones esenciales

\begin{abstract}
This paper intends to find out in TS Eliot's essay, Notes Towards the Definition of Culture, his concept of culture and the importance of cultural studies in language teaching and the development of modern society. T. S. Eliot wants to know whether "essential conditions" for the growth and survival of culture do exist. For Eliot, the interaction between the culture of the "individual, group, and society" is fundamental. In this framework of ideas I will share the experience of two Modern Languages School projects: Encuentro Mesoamericano "Escritura-Cultura" (ED-2080), which has reflected since 2006 on the interaction between "individual-groupsociety", considering the centrality of the human person as the basis of
\end{abstract}


an authentic culture and development. And Literary Research works in modern languages (English, German, French, Italian) (No. 23-B3-194), which has been approaching since 2013 literary criticism from an axiological and personalistic point of view.

Key words: T. S. Eliot, Notes Towards the Definition of Culture, individual-group-society, culture

\section{Introducción}

$\mathrm{T}$ S. Eliot en su ensayo de 1948, Notes towards the Definition of Culture, plantea unos retos interesantes que tienen consecuencias prácticas en la investigación, en la pedagogía de lenguas y en el desarrollo de la sociedad actual. A la luz de las afirmaciones que hace Eliot sobre las condiciones esenciales para el crecimiento de la cultura, daré a conocer la experiencia de dos proyectos $^{1}$ que coordino para la Escuela de Lenguas Modernas, los cuales sintonizan con las ideas clave del ensayo de Eliot, y que han generado la propuesta de un marco teórico que denomino personalismo literario ${ }^{2}$, y un enfoque para abordar el tema de la creación y de la crítica literaria: la centralidad de la persona humana para la cultura.

Del ensayo de Eliot entresacaré algunas ideas inspiradoras que plantea como condiciones esenciales para el crecimiento de la cultura. Empieza por aclarar que su objetivo es ayudar a definir la palabra cultura. La primera afirmación que establece es la de la relación esencial que existe entre cultura y religión ${ }^{3}$.

\section{Condiciones esenciales para el crecimiento de la cultura}

Me referiré a continuación a algunas condiciones que señala Eliot:
- La interacción entre individuogrupo-sociedad

- La relación vital entre cultura y religión

- La cultura como "estilo de vida"

- La familia, canal primario para la transmisión de la cultura

- Unidad y diversidad

\section{La interacción entre individuo- grupo-sociedad}

Eliot establece la necesidad de la interacción entre la cultura del individuo, la del grupo y la de la sociedad. Dice que constantemente estamos asistiendo al nacimiento de una civilización y plantea la necesidad de enriquecer la cultura que nos toca vivir. Se pregunta si existe un estándar permanente para poder establecer una comparación entre una civilización y otra. Afirma que ninguna sociedad o edad de la historia es capaz de realizar todos los valores de la civilización; podemos solamente distinguir entre culturas que son más elevadas y otras que no lo son tanto. Concluye que la cultura es una de las cosas que no podemos buscar (apuntar hacia) deliberadamente, porque siempre será el resultado de una variedad más o menos armoniosa de actividades que se persiguen por sí mismas en cada campo: el pintor frente a su lienzo, el poeta frente a la hoja, el funcionario civil frente a la resolución de un problema... (19). La 
cultura no es "producto" de esquemas organizativos. Surge de la condición natural del ser humano, que así como busca su mejora individual, también está atento a la mejora del grupo, y a la de la sociedad, sabiendo que esto se logra en "cosas pequeñas", estando atento a lo cotidiano".

El término cultura tiene, según Eliot, tres sentidos diferentes, dependiendo de si se refiere al individuo, al grupo o a la sociedad. Afirma con convicción que la cultura del individuo depende de la cultura del grupo, y la cultura del grupo depende de la cultura de la sociedad. La cultura se hace "inteligible" cuando el cultivo personal del individuo se pone en contacto con la cultura del grupo y de la sociedad (21).

Eliot está convencido de que la cultura del individuo no se puede aislar de la cultura del grupo, y la cultura del grupo tampoco se debe aislar de la cultura de la sociedad. La noción de "perfección" en la cultura ha de tomar en cuenta todos esos tres sentidos de la cultura (24). El hecho de que surjan grupos culturales más "elevados" tiene su impacto en la sociedad: es parte de un proceso en el cual toda la sociedad cambia. Si surgen nuevos valores, el pensamiento la sensibilidad y la expresión se tornan más elaborados, haciendo así que vayan desapareciendo valores anteriores.

\section{La relación vital entre cultura y religión}

Eliot, a lo largo de su ensayo, va explorando la relación vital existente entre cultura y religión. Se plantea si el refinamiento de la cultura incide en el progreso de la religión, o más bien si el progreso de la religión causa el re- finamiento de la cultura ${ }^{5}$. Pone como ejemplo el efecto profundo que tuvo el cristianismo en el pensamiento y en las costumbres al penetrar la cultura grecorromana. Se pregunta si una cultura puede generarse o mantenerse sin una base religiosa. $\mathrm{Al}$ respecto llega Eliot a hacer esta afirmación luminosa: la cultura es esencialmente la "encarnación" de la religión de un pueblo . $^{2}$

Para Eliot, cultura y religión son diferentes aspectos de una misma realidad. Señala dos errores complementarios. El primero: que la cultura pueda preservarse, extenderse y desarrollarse en ausencia de la religión. Y el segundo: que la preservación y el sostenimiento de la religión pueda darse al margen de la cultura. Hace esta aguda observación: "Aesthetic sensibility must be extended into spiritual perception, and spiritual perception must be extended into aesthetic sensibility and disciplined taste..." (30).

Solo así, opina Eliot, se puede estar en condiciones para emitir un juicio sobre la decadencia o sobre la presencia de lo diabólico y nihilista en el arte: "To judge a work of art by artistic or by religious standards, to judge a religion by religious or artistic standards should come in the end to the same thing: though it is an end at which no individual can arrive" (30).

Eliot está consciente de la dificultad existente para captar esa relación esencial entre cultura y religión: "The way of looking at culture and religion which I have been trying to adumbrate is so difficult that I am not sure I grasp it myself in flashes, or that I comprehend all its implications" (30).

Afirma que aunque la religión y la cultura significan cosas diferentes, deberían ser para el individuo y el grupo algo 
hacia lo cual se "tiende" -en el sentido de conquista-, y no algo que se "posee":

Yet there is an aspect in which we can see a religion as the whole way of life of a people, from birth to the grave, from morning to night and even sleep, and that way of life is also its culture...

...what is part of our culture is also part of our lived religion (31).

Para aprehender la teoría de la cultura y de la religión de Eliot es preciso, dice él, evitar dos errores alternativos: el de considerar la cultura y la religión como dos asuntos separados entre los cuales existe una relación, y el de identificar cultura y religión. Al afirmar Eliot que la cultura de un pueblo es la "encarnación" de su religión, piensa que así se pueden impedir esos dos errores: el de evitar la relación entre cultura y religión, y el de identificar religión y cultura. Y concluye: “... any religion while it lasts, and on its own level, gives an apparent meaning to life, provides the frame-work for a culture, and protects the mass of humanity from boredom and despair" (34).

\section{La cultura como "estilo de vida"}

Para Eliot, la cultura es la expresión de las actividades e intereses característicos de un pueblo (31), es algo vivo y que está en íntima relación con las creencias de un pueblo. Es un "estilo de vida" donde lo que se cree no se disocia de lo que se vive ("behaviour is also belief"). Se trata de una meta muy alta por la que se lucha ${ }^{7}$. Eliot alude incluso a la necesidad de un auxilio que sobrepase lo humano para poder "encarnar" esta unidad: "When we consider the quality of the integration required for the full cultivation of the spiritual life, we must keep in mind the possibility of grace and the exemplars of sanctity in order not to sink in despair" (32).

La cultura no es la suma, afirma Eliot, de distintas actividades culturales. La cultura no se capta meramente observando en detalle todas estas manifestaciones en su conjunto. Entender la cultura es entender un pueblo y su estilo de vida ${ }^{8}$. Luego hace la afirmación interesante de que no necesariamente el "genio" artístico hace "culta" a una persona (41). Esta persona puede considerarse como "contribuidora", pero no necesariamente es una persona "culta"; para esto se requiere el cultivo de "maneras"9 que constituyen unos elementos vitales para la cultura.

\section{La familia, canal primario para la transmisión de la cultura}

Para Eliot el canal primario de transmisión de la cultura es la familia: "The primary cannel of transmission of culture is the family: no man wholly escapes from the kind, or wholly surpasses the degree of culture which he acquired from his early environment" (43).

La familia marca todo un estilo de vida y el aprendizaje se limita, no solo a volverse "diestro" en el manejo de una técnica, sino en adquirir toda una manera de vivir y de enfocar la vida. Llega a afirmar que cuando la familia deja de influir es de esperar el deterioro de la cultura ${ }^{10}$.

Eliot clarifica lo que entiende por "vínculo" familiar:

...when I speak of the family, I have in mind a bond which embraces a longer 
period of time...: a piety towards the dead, however obscure, and a solicitude for the unborn, however remote. Unless this reverence for past and future is cultivated in the home, it can never be more than a verbal convention in the community. Such an interest in the past is different from the vanities and pretensions of genealogy; such a responsibility for the future is different from that of the builder of social programmes (44).

Para Eliot es importante una estructura de sociedad en la que exista -de "arriba" hacia "abajo"- una gradación continua de niveles culturales. Afirma que los niveles culturales más "altos" no necesariamente son más "cultos" que los niveles más "bajos"; representan sencillamente una cultura más consciente y tienen una mayor especialización. La democracia verdadera, afirma Eliot, solo puede mantenerse si contiene esta gradación de diferentes niveles de cultura.

Para preservar y defender esta sociedad con gradación de niveles culturales, la familia juega un papel importante:

If we agree that the primary vehicle for the transmission of culture is the family, and if we agree that in a more highly civilized society there must be different levels of culture, then it follows that to ensure the transmission of the culture of these different levels there must be groups of families persisting, from generation to generation, each in the same way of life (48).

\section{Unidad y diversidad}

Para Eliot es importante que cada región tenga su cultura característica, y que sea una cultura que armonice, se relacione ${ }^{11}$, y enriquezca las culturas de otras regiones. Emplea el hermoso título "constelación" de culturas ${ }^{12}$. Afirma que lo propio de todo ser viviente es el "instinto" de persistir en su propio ser:

... it is the instinct of every living thing to persist in its own being.

... any vigorous small people wants to preserve its individuality.

... the survival of the satellite culture is of very great value to the stronger culture (55).

Un pueblo será juzgado históricamente, en última instancia, de acuerdo con la contribución que hace a las culturas que surgen posteriormente.

La preservación de una lengua juega un papel importante en la transmisión de la cultura: “... for the transmission of a culture -and for its maintenance, there is no safeguard more reliable than a language" (57).

Acuña el hermoso término de "ecología de las culturas" para explicar la interacción de la diversidad en la unidad. Habla del efecto saludable de la "fricción" propia de la diversidad: "Indeed, the more the better: so that everyone should be an ally of everyone else in some respects, and an opponent in several others" (59).

Para Eliot, el encuentro entre individuos y cultura es fundamental: "As individuals, we find that our development depends upon the people whom we meet in the course of our lives" (59).

El encuentro se enriquece tanto por las afinidades como por las diferencias:

The benefit of these meetings is due as much to the differences as to the resemblances; to the conflict, as well as the sympathy between persons. 
Fortunate the man who, at the right moment, meets the right friend; fortunate also the man who at the right moment meets the right enemy... (59).

Eliot llega hasta afirmar que "el enemigo" es saludable, y que las diferencias enriquecen:

I do not approve the extermination of the enemy: the policy of exterminating... is one of the most alarming developments of modern war and peace, from the point of view of those who desire the survival of culture. One needs the enemy. So, within limits, the friction, not only between individuals but between groups, seems to me quite necessary for civilization (29).

Para Eliot, una cultura nacional debe ser la resultante de un indefinido número de culturas locales, las cuales están constituidas a su vez por culturas locales todavía más pequeñas.

Una cultura nacional mejora cuando se ponen en contacto con culturas extranjeras donde ambas intercambian -dan y reciben-su legado cultural.

Eliot rechaza todo intento mundial de "planificación"13 de la cultura (los "world-planners") y afirma categóricamente: "a world culture which was simply a uniform culture would be no culture at all" (62).

Eliot rechaza también la destrucción deliberada de una cultura: “... the deliberate destruction of another culture as a whole is an irreparable wrong, almost as evil as to treat human beings like animals" (65).

Concluye hablando sobre el ideal que late en todas las culturas- por alcanzar una cima de unidad más alta y que solo puede otorgar una fe común:
... the culture of a nation prospers with the prosperity of the culture of its several constituents, both geographical and social; but it also needs to be itself a part of a larger culture, which requires the ultimate ideal, however unrealizable, of a 'world culture' in a sense different from that implicit in the schemes of world-federations. And without a common faith, all efforts towards drawing nations closer together in culture can produce only an illusion of unity (82).

En el apéndice que incluye Eliot al final de su ensayo se plantea a qué se debe la unidad en la diversidad en la cultura Europea. Afirma que se debe al cristianismo:

The dominant force in creating a common culture between peoples each of which has its distinct culture is religion... ... the common tradition of Christianity which has made Europe what it is, and... the common cultural elements which this common Christianity has brought with it (122).

Luego señala un largo elenco para ejemplificar la influencia del cristianismo en las artes, en las leyes, en la concepción de la moral pública y privada, en los estándares comunes en literatura... Afirma que solo una cultura cristiana pudo haber producido un Voltaire o un Nietzsche. Eliot opina que Europa sin raíces cristianas se desmoronaría:

I do not believe that the culture of Europe could survive the complete disappearance of the Christian Faith. And I am convinced of that, not merely because I am a Christian myself, but as a student of social biology. If Christianity goes, the whole of our culture goes. 
Then you must start painfully again, and you cannot put on a new culture ready made. You must wait for the grass to grow to feed the sheep to give the wool out of which a new coat will be made. You must pass through many centuries of barbarism (122).

La unidad característica que observamos en Europa se debe a la herencia del cristianismo, la cual se nutre a su vez de las antiguas civilizaciones de Grecia, Roma e Israel. Califica esta herencia como el verdadero "vínculo" que les une:

What I wish to say is, that this unity in the common elements of culture, throughout many centuries, is the true bond between us. No political and economic organization, however much goodwill it commands, can supply what this cultural unity gives. If we dissipate or throw away our common patrimony of culture, then all the organization and planning of the most ingenious minds will not help us, or bring us closer together (123).

Proféticas resultan estas palabras pronunciadas por Eliot en Berlín en 1946 (9). La unidad europea no está en la "moneda" -el euro-, sino en sus raíces cristianas.

Eliot concluye con una invitación a que nos volvamos "custodios" del legado cultural que hemos recibido porque en un mundo caracterizado hoy por la devastación "material", se corre el peligro de perder la herencia "espiritual".

\section{La experiencia de dos proyectos de la Escuela de Lenguas Modernas}

A continuación daré a conocer dos proyectos que coordino para la Escuela de Lenguas Modernas, uno de Acción Social y otro de Investigación, que sintonizan con las ideas expuestas por T.S.Eliot en su ensayo Notes towards the Definition of Culture.

El proyecto de Acción Social iniciado en el año 2006, Encuentro Mesoamericano "Escritura- Cultura", explora la interacción individuo-gruposociedad de la región mesoamericana y plantea la centralidad de la persona humana como base de una auténtica cultura y desarrollo:

El Proyecto del Encuentro Mesoamericano "Escritura-Cultura" constituye un encuentro anual de escritores, pensadores, comunicadores y docentes, para celebrar las letras centroamericanas y su relación con las letras de otros países. La escritura es una de las más hermosas expresiones de la dignidad de la persona. Es uno de los principales pilares de la Cultura. Mesoamérica, en el corazón del continente americano, es una letra en el libro de la cultura universal. Unir el pasado al presente y vislumbrar el futuro, por el recuerdo y el estudio de clásicos, contemporáneos e inéditos. Estudio y reflexión que faciliten conocernos mejor y reafirmar la dignidad de la persona, fuente de la auténtica cultura. Desarrollo es persona. Desarrollo es cultura.

El interés constante durante estos nueve años ha sido poner en contacto las culturas locales de la región mesoamericana con el fin de conocernos mejor en las dos vertientes de la creación y de la crítica literarias. También ha sido de vital importancia contrastar esta región mesoamericana con las culturas de otras regiones, mediante el estudio 
de autores clásicos, contemporáneos e inéditos. El balance de estos años ha sido la participación de 117 investigadores internacionales y nacionales, 257 investigaciones publicadas, 107 escritoras y escritores estudiados ${ }^{14}$. Se ha mantenido el enfoque multidisciplinario con los aportes de la estética, antropología, filosofía, psicología, teoría y crítica literarias, pedagogía..., en un esfuerzo por conjugar la riqueza de diferentes perspectivas en el estudio de las letras mesoamericanas. Como fruto de este quehacer académico se ha impulsado un enfoque personalista del estudio de la literatura, cuyos frutos fueron publicados en el año 2014 en la obra colectiva: Literatura y personalismo: una mirada profunda.

El proyecto Investigaciones Literarias de obras en lenguas modernas (alemana, francesa, inglesa, italiana): Estudio y comentario del plan de lecturas del Ministerio de Educación Pública, se inserta en el marco de la literatura universal, con el fin de brindar un estudio y comentario de las obras que los docentes del sistema educativo nacional deben analizar en su plan de lecturas. Este estudio se ha ido abordando con un enfoque axiológico personalista, basado en la filosofía personalista y en el método lúdico-ambital de crítica literaria del Dr. Alfonso López Quintás. Una muestra de este quehacer se desarrolló durante el Taller que ofrecimos en el Congreso, donde dimos a conocer el marco teórico del personalismo literario y su aplicación en la obra El principito de Antoine de Saint Exupéry.

Estos dos proyectos de la Escuela de Lenguas Modernas vienen coincidiendo con las líneas directrices propuestas por Eliot en su ensayo. Confirman la validez y fecundidad de su enfoque sobre la cultura. Y podemos concluir que cuando el quehacer cultural contempla las condiciones esenciales que señala Eliot para el crecimiento de la cultura, podemos esperar el nacimiento de una civilización cada vez más humana y humanizadora ${ }^{15}$.

\section{Notas}

1 Encuentro Mesoamericano "Escritura-Cultura": Proyecto ED-2080, inscrito desde 2006 en la Vicerrectoría de Acción Social. Declarado de Interés Cultural por la Presidencia de la República y el Ministerio de Cultura (No. 042-C del 13 de junio del 2006).

Investigaciones Literarias de obras de lenguas modernas (alemana, francesa, inglesa e italiana): Estudio y comentario del plan de lecturas del Ministerio de Educación Pública: Proyecto de investigación 23-B3-194 inscrito desde 2013 en la Vicerrectoría de Investigación.

2 Cfr. La obra colectiva de Helena Ospina y Gabriel Quesada Mora (Eds.), Literatura y personalismo: una mirada profunda. San José: Promesa, 2014.

3 "The first important assertion is that no culture has appeared or developed except together with a religion..." (15).

"The artistic sensibility is impoverished by its divorce from the religious sensibility, the religious by its separation from the artistic..." (26).

"...no culture can appear or develop except in relation to a religion" (27).

"... the formation of a religion is also the formation of a culture" (73).

4 "...we should look for the improvement of society, as we seek our own individual improvement, in relatively minute particulars. We cannot say: 'I shall make myself 
into a different person'; we can only say: 'I shall make myself into a different person'; we can only say: 'I will give up this bad habit, and endeavour to contract this good one.' So of society we can only say: 'We shall try to improve it in this respect or the other, where excess or defect is evident; we must try at the same time to embrace so much in our view... Even this is to express an aspiration greater than we can achieve: for it is as much, or more, because of what we do piecemeal without understanding or foreseeing the consequences, that the culture of one age differs from that of its predecessor" (20).

5 "...we may ask whether any culture could come into being, or maintain itself, without a religious basis" (28).

6 "We may go further and ask whether what we call the culture, and what we call the religion of a people are not different aspects of the same thing: the culture being, essentially, the incarnation (so to speak) of the religion of a people" (28).

7 San Josemaría Escrivá se refiere a esta meta con el nombre de "unidad de vida", donde lo que se piensa es lo que se expresa y lo que se vive. Es una unidad que se conquista día a día en una lucha constante por ser "coherente" y obrar en consecuencia.

8 "Culture is not merely the sum of several activities, but a way of life" (41).

9 La escritora norteamericana Flannery O'Connor tiene unos espléndidos ensayos sobre este tema en su obra Mystery and manners.

10 "But by far the most important channel of transmission of culture remains the family: and when family life fails to play its part, we must expect our culture to deteriorate" (43).

11 For the health of the culture of Europe two conditions are required: that the culture of each country should be unique, and that the different cultures should recognize their relationship to each other, so that each should be susceptible of influence from the others. And this is possible because there is a common element in European culture, an interrelated history of thought and feelings and behaviour, an interchange of arts and of ideas" (119).

12 For a national culture, if it is to flourish, should be a constellation of cultures, the constituents of which, benefiting each other, benefit the whole" (58).

13 "Culture can never be wholly conscious -there is always more to it than we are conscious of; and it cannot be planned because it is also the unconscious background of all our planning" (94).

14 Cfr. Investigaciones Literarias Interdisciplinares 2006-2013, publicadas en las Actas de los Encuentros Mesoamericanos "Escritura-Cultura"y de los Coloquios Escritoras y Escritores Latinoamericanos.

15 "And once again I must repeat, that the 'conditions of culture' which I have set forth do not necessarily produce the higher civilization; I assert only that when they are absent, the higher civilization is unlikely to be found" (49).

\section{Bibliografía}

Araya Rivas, Fernando. "Persona, cultura y economía". Actas del II Encuentro mesoamericano "EscrituraCultura”: clásicos, contemporáneos, inéditos. Ed. Helena Ospina. San José, C.R: Universidad de Costa Rica; Promesa, 2008. 337-351. Impreso. Banús, Enrique. "Hoffman: Cuentos". Nueva literatura para un nuevo siglo. Actas del VIII Encuentro Mesoamericano "Escritura-Cultura" $y$ del VI Coloquio Escritoras y Escritores Latinoamericanos. Ed. Helena 
Ospina. San José, C.R: Universidad de Costa Rica; Promesa, 2014. 216230. Impreso.

“QQué es cultura?”. Proyección social y responsabilidad del autor. Actas del III Encuentro Mesoamericano "Escritura-Cultura" y del I Coloquio Escritoras y Escritores Latinoamericanos. Ed. Helena Ospina. San José, C.R: Universidad de Costa Rica; Promesa, 2009. 24-48. Impreso.

Chinchilla Ramírez, Erika. "La cultura como empresa editorial, creativa y académica". Editores y Escritores: Dos protagonistas inseparables. Actas del IV Encuentro Mesoamericano "Escritura-Cultura" y del II Coloquio Escritoras y Escritores Latinoamericanos. Ed. Helena Ospina. San José, C.R: Universidad de Costa Rica; Promesa, 2010. 134-143. Impreso.

Cruz Bertolone, Iris. "Francesco D' Adamo: La historia de Iqbal".Nueva literatura para un nuevo siglo. Actas del VIII Encuentro Mesoamericano "Escritura-Cultura" y del VI Coloquio Escritoras y Escritores Latinoamericanos. Ed. Helena Ospina. San José, C.R: Universidad de Costa Rica; Promesa, 2014. 267-285. Impreso.

Eliot, T.S. Notes towards the Definition of Culture, 1948. London: Faber and Faber Limited, 1972. Print

Gaiba, Gloria. "Pinocho "c'est moi" de Collodi". La comunicación de la belleza a través de la palabra: su actor y su receptor. Actas del VI Encuentro Mesoamericano "EscrituraCultura" y del IV Coloquio Escritoras y Escritores Latinoamericanos. Ed. Helena Ospina. San José, C.R: Promesa, 2012. 127-154. Impreso.
Guevara Quiel, Francisco. "Las fábulas de La Fontaine". La comunicación de la belleza a través de la palabra: su actor y su receptor. Actas del VI Encuentro Mesoamericano "Escritura-Cultura" y del IV Coloquio Escritora y Escritores Latinoamericanos. Ed. Helena Ospina. San José, C.R: Universidad de Costa Rica; Promesa, 2012. 110-126. Impreso.

González Zúñiga, Julián. "La lección de Eugène Ionesco y el teatro del absurdo". Pensamiento, literatura, independencia. Actas del VII Encuentro Mesoamericano EscrituraCultura, 2012. UCR- Promesa, San José, 2013. 260-269. Impreso.

Llano, Alejandro. Cultura y pasión. Pamplona: Eunsa, 2007. Impreso.

López Quintás, Alfonso. Literatura francesa del siglo XX. Sartre, SaintExupéry, Camus, Anouilh, Beckett. San José: Promesa, 2011. Impreso.

Ospina Garcés, Helena. "El concepto de cultura en Camino". Memoria del Congreso Hispanoamericano: Hacia una educación más humana. En torno al pensamiento de Josemaría Escrivá. 21 al 22 set. 2001. Ed. ADEC. San José: Promesa, 2002. 177-197. Impreso.

"La cultura como servicio". Escritores y lectores. Persona y personajes. Derechos y deberes. Actas del $V$ Encuentro Mesoamericano "Escritura-Cultura" y del III Coloquio Escritoras y Escritores Latinoamericanos. Ed. Helena Ospina. San José, C.R: Universidad de Costa Rica; Promesa, 2011. 501-507. Impreso.

. "Los Encuentros Mesoamericanos: Foros de estudio sobre aspectos medulares de la cultura”. La comunicación de la belleza a través de 
la palabra. Su actor y su receptor. Actas del VI Encuentro Mesoamericano "Escritura-Cultura" y del IV Coloquio "Escritoras y Escritores Latinoamericanos". Universidad de Costa Rica. 22 al 23 set. 2011. Ed. Helena Ospina. San José: Promesa, 2012. 22-30. Impreso.

"Los estudios literarios en palabras de los investigadores". Editores y escritores: Dos protagonistas inseparables. Actas del IV Encuentro Mesoamericano "Escritura-Cultura" y del II Coloquio "Escritoras y Escritores Latinoamericanos". Universidad de Costa Rica. 13 al 14 agosto 2009. Ed. Helena Ospina. San José: Promesa, 2010. 276-281. Impreso.

"El impacto de Camino en la cultura". Camino: Un encuentro histórico, literario y periodístico. Ed. Alicia Vargas Fournier et al. San José: Promesa, 2002. 37-50. Impreso.

"Las investigaciones en el área de humanidades: fuentes de desarrollo y productividad en la universidad". Escritores y lectores: Persona $y$ personajes. Derechos y deberes. Actas del V Encuentro Mesoamericano "Escritura-Cultura" y del III Coloquio "Escritoras y Escritores Latinoamericanos". Universidad de Costa Rica. 20 al 21 set. 2010. Ed. Helena Ospina. San José: Promesa, 2011. 250-255. Impreso.

"John Paul II's Letter to Artists: The Cultural Implications". Actas del VI Congreso "Cultura Europea" de la Universidad de Navarra. 25 al 28 oct. 2000 . Eds. Enrique Banús y Beatriz Elio. Pamplona: Editorial Aranzadi, 2002. 10371049. Impreso.
, y Gabriel Quesada Mora, eds. Literatura y personalismo: Una mirada profunda. San José: Promesa, 2014. Impreso.

"La mujer y la cultura en el siglo XXI: Una experiencia de reflexión, gestión y creatividad". Primer Ideario Costarricense del Siglo XXI. Heredia: Universidad Nacional, 2010. 416-431. Impreso.

"Naturaleza y objetivos de los Encuentros Mesoamericanos 'Escritura-Cultura"'. Revista de Lenguas Modernas. Universidad de Costa Rica. 6 (enero-junio, 2007): 175-177. Impreso.

, y Jorge Mario Cabrera Valverde. "Nuevas propuestas estéticas para un desarrollo integral de la cultura". Grupo de Trabajo no. 9 (Workshops, Talleres). Actas del V Congreso "Cultura Europea" de la Universidad de Navarra. 23 al 31 oct. 1998. Eds. Enrique Banús y Beatriz Elio. Pamplona: Editorial Aranzadi, 2000. 1158-1159. Impreso. "Persona y cultura. La inculturación de la fe: crisis y desafío para el tercer milenio". Actas del $V$ Congreso "Cultura Europea" de la Universidad de Navarra. 23 al 31 oct. 1998. Eds. Enrique Banús y Beatriz Elio. Pamplona: Editorial Aranzadi, 2000. 569-579. Impreso. "Proyección de las investigaciones en Humanidades: verdadero cultivo de 'los bienes invisibles' para la cultura". La comunicación de la belleza a través de la palabra. Su actor y su receptor. Actas del VI Encuentro Mesoamericano "Escritura-Cultura" y del IV Coloquio "Escritoras y Escritores Latinoamericanos". Universidad de Costa Rica. 22 al 23 set. 2011. Ed. Helena 
Ospina. San José: Promesa, 2012. 362-368. Impreso.

.Voz "Cultura". Diccionario de San Josemaría Escrivá de Balaguer. Coord. José Luis Illanes. Instituto Histórico San Josemaría Escrivá de Balaguer. Burgos: Editorial Monte Carmelo, 2013. 303304. Impreso.

Quesada Mora, Gabriel. "Hacia una mirada personalista de la literatura". Pensamiento. Literatura. Independencia. Actas del VII Encuentro Mesoamericano "Escritura-Cultura" y del V Coloquio Escritoras y Escritores Latinoamericanos. Ed. Helena Ospina. San José, C.R: Universidad de Costa Rica; Promesa, 2013. 153-171. Impreso.

Quirós Rodríguez, Manuel Antonio. "Análisis de los vocablos "palabra" y "cultura"". Nueva literatura para un nuevo siglo. Actas del VIII Encuentro Mesoamericano "EscrituraCultura" y del VI Coloquio Escritoras y Escritores Latinoamericanos. Ed. Helena Ospina. San José, C.R: Universidad de Costa Rica; Promesa, 2014. 78-102. Impreso.

Schulze Boysen, Susanne. "Cornelia Funke: Corazón de tinta.Nueva literatura para un nuevo siglo. Actas del VIII Encuentro Mesoamericano "Escritura-Cultura" y del VI Coloquio Escritoras y Escritores Latinoamericanos. Ed. Helena Ospina. San José, C.R: Universidad de Costa Rica; Promesa, 2014. 231-238. Impreso

Vega González, Rómulo. "El Lute-Song en las obras de Shakespeare". Pensamiento. Literatura. Independencia. Actas del VII Encuentro Mesoamericano "Escritura- Cultura" y del V Coloquio Escritoras y
Escritores Latinoamericanos. Ed. Helena Ospina. San José, C.R: Universidad de Costa Rica; Promesa, 2013. 281-287. Impreso.

Zelaya Lücke, Ana. "Walt Whitman el escritor revolucionario de la expresión poética estadounidense. Poesía: Hojas de hierba". Nueva literatura para un nuevo siglo. Actas del VIII Encuentro Mesoamericano "Escritura-Cultura" y del VI Coloquio Escritoras y Escritores Latinoamericanos. Ed. Helena Ospina. San José, C.R: Universidad de Costa Rica; Promesa, 2014. 255-266. Impreso. 